\title{
Vulnerability of Archeological Sites in East Texas
}

James E. Corbin

Unknown

Follow this and additional works at: https://scholarworks.sfasu.edu/ita

Part of the American Material Culture Commons, Archaeological Anthropology Commons, Environmental Studies Commons, Other American Studies Commons, Other Arts and Humanities Commons, Other History of Art, Architecture, and Archaeology Commons, and the United States History Commons

Tell us how this article helped you.

This Article is brought to you for free and open access by the Center for Regional Heritage Research at SFA ScholarWorks. It has been accepted for inclusion in Index of Texas Archaeology: Open Access Gray Literature from the Lone Star State by an authorized editor of SFA ScholarWorks. For more information, please contact cdsscholarworks@sfasu.edu. 


\section{Vulnerability of Archeological Sites in East Texas}

Creative Commons License

(c) (i) (8)

This work is licensed under a Creative Commons Attribution-NonCommercial 4.0 International License 


\section{Vulnerability of Archaeological Sites in East Texas}

\section{James E. Corbin}

A discussion concerning the vulnerable archeological sites in East Texas, or anywhere for that matter, is a serious and complex one, primarily because all archaeological sites are vulnerable. Of course, it must be understood that it is the very nature of archaeological sites to be threatened with destruction.

From the moment of its inception, an archaeological site is faced with destruction; the formation process of the archeological site with which we are generally concerned is one of destruction of the cultural information we are trying to recover and protect. Although in this light we tend to attribute the destructive forces to that ever industrious creature, Mother Nature, humans have always been a part of the destructive process.

The "First Archaeological" Site was more than likely soon threatened and then impacted by whomever the second inhabitants of that site were. Consider the archaeological site known as 41NA113, the Adolphus Sterne Site. It was first occupied approximately 4000 years ago. The first significant human impact came some 2000 years later with the construction of firepits, trashpits, and houses of the Early Ceramic Period inhabitants. Six hundred years later, Caddoan folks constructed a house, storage pits, etc., on and into the earlier archaeological remains. In 1779, Domingo Martinez excavated wall trenches and post holes to build his "palisado" house. Adolphus Sterne, in 1831, then excavated a large cellar into the site and constructed his house over the location of Martinez' house floor. Subsequent swept yards, a grave, a sunken greenhouse, gardens, and chimney foundations continue to ravage the site.

Today, we, as conservators of the past fight a daily battle at this site, and other sites, to further protect them from the attacks of an ever-growing population. Since human societies have generally all had similar needs in terms of a place to live, it is those sites coming under the attack of urbanization in East Texas that are ultimately the most and immediately vulnerable. Given that it is probably impossible to protect sites from the ravages of Nature and human activity, it behooves us to make every effort to protect what sites we can in an effort to preserve the cultural heritage of Texas. 